\title{
MEMBATASI k-KETENGGAAN SIMPUL DALAM PEMBANGKITAN RANDOM GRAPH METODE ERDOS ROYI UNTUK MENINGKATKAN KINERJA KOMPUTASI
}

\author{
Zainal Abidin'1 dan Agus Zainal Arifin² \\ ${ }^{1}$ Jurusan Teknik Informatika Fakultas Sains dan Teknologi UIN Maulana Malik Ibrahim Malang. \\ ${ }_{2}^{2}$ Jurusan Informatika Fakultas Teknologi Informatika Institut Teknologi Sepuluh Nopember \\ Keputih, Sukolilo, Surabaya, Indonesia \\ e-mail : ${ }^{1}$ br52s@cs.its.ac.id, ${ }^{2}$ agusza@cs.its.ac.id
}

\begin{abstract}
Edges generation by random graph erdos-royi methods was needed high computation, it's caused low performance. In fact, edge generation was used frequently with many nodes. this paper is described a node restriction by $k$-nearest neighbour on edge generation of random graph erdos royi method. Result of node restriction by k-nearest neighbour can be reduced computation time.
\end{abstract}

Keywords: random Graph, erdos royi, k-nearest neighbour, computation time.

\section{PENDAHULUAN}

Graph adalah himpunan simpul dan busur yang menghubungkan semua atau beberapa simpul (Diestel, 2000). Graph dengan anggota simpul-simpul tidak saling terhubung antar satu dan simpul lain disebut Graph terisolasi. Pembangkitan busur dari Graph terisolasi sering digunakan sebagai sarana untuk simulasi.

Simulasi Graph sering digunakan untuk mengetahui hubungan antar penulis dan pembimbing dalam melakukan aktifitas penelitian (Newman, 2001a). Graph yang terbentuk bisa diketahui seberapa banyak seorang peneliti melakukan pembimbingan. Banyaknya bimbingan dapat diketahui dari jumlah busur yang terhubung keluar dari simpul peneliti dan bobotnya. Graph dipakai untuk melihat karya peneliti terbaik (Newman, 2001b). Karya tulis dianggap sebauh simpul kemudian dibangkitkan busur kearahnya jika ada karya tulis yang mengacu pada karya tulis tersebut.

Graph digunakan untuk mengetahui seberan dari sel tumor otak (Gunduz, 2004; Demir 2005). Sel-sel dari otak dianggap sebagai suatu simpul. Simpul-simpul yang diperoleh dibangkitkan busur-busur menggunakan suatu probabilitas. Probilitas digunakan untuk menentukan batas apakah suatu simpul terhubung atau tidak terhubung dengan simpul yang lain. Graph dipakai mengukur dan menganalisa kerapatan (Abidin dan Arifin, 2008; Abidin dan Arifin, 2009).

Simpul-simpul yang digunakan untuk membangkitkan busur berjumlah ribuan. Simpul digunakan dalam deteksi sebaran sel tumor sejumlah sekitar 4000 buah (Gunduz, 2004; Demir 2005). Simpul digunakan dalam analisa kerapatan berjumlah antara 2000 sampai dengan sekitar 7000 buah (Abidin dan Arifin, 2008; Abidin dan Arifin, 2009). Random Graph dengan metode erdos royi adalah membangkitkan Graph dari Graph terisolasi dengan membangkitkan busur dari setiap simpul dengan semua simpul dengan suatu batasan sebuah probabilitas (Watts dan Strogatz, 1998). Menghubungkan setiap simpul ke semua simpul yang lain memerlukan komputasi yang besar. Persamaan 1 merupakan jumlah busur B yang mungkin terbentuk dengan jumlah simpul n.

$$
B=1 / 2 n(n-1) \text {. }
$$

Komputasi besar membuat kinerja komputer jadi rendah. Prosesor dari komputer jadi sibuk. Pembangkitan random Graph metode erdos royi masih dapat ditingkatkan kinerjanya. Pembatasan dalam bentuk probalitas antar simpul dapat digunakan sebagai dasar peningkatan kinerja. Jika pembangkitan dibatasi dengan probablitas, maka tidak perlu setiap simpul dicoba dibangkitan busur dan dihitung probablitasnya, tetapi mungkin hanya perlu dicoba pada simpul-simpul terdekatnya saja. Sejumlah $\mathrm{n}$ simpul terdekat atau ketetanggaan diberi notasi $n$-ketetangggan. Dalam penelitian ini menjelaskan tentang pembatasan simpul sejumlah n-ketetanggan untuk peningkatan kinerja pada pembangkitan Graph dengan metode erdos dan royi. 


\section{KAJIAN GRAPH}

\section{A. Dasar-dasar Graph}

Graph $(G)$ adalah himpunan simpul (vertex, $V$ ) dan busur (edge, $E)$, ditulis dengan $G=(V, E)$ (Reinhard Diestel, 2000). Graph ditampilkan dalam titik dan garis. Titik adalah lambang dari simpul. Garis merupakan lambang dari busur yang menghubungkan antara dua simpul. Ukuran (size, order) Graph $G,|G|$ adalah jumlah simpul yang menjadi anggota himpunan dari Graph, walaupun simpul tersebut tidak dihubungkan oleh suatu busur. Jumlah busur dituliskan dengan $\|G\|$. Gambar 1, contoh Graph dengan ukuran 7. Simpul nomor enam tidak terhubung ke simpul yang lain.

Graph pada Gambar 1 dapat ditulis dalam bentuk himpunan simpul $V$ dan busur $E$, misal, $V$ $=\{1,2,3,4,5,6,7\}, E=\{\{1,2\},\{1,5\},\{2,5\},\{3,4\}$, $\{5,7\}\}$. Busur $\{x, y\}$ dapat tulis dengan busur $x y$ atau $y x$. Simpul $x$ dan $y$ dari Graph $G$ dikatakan saling berketetanggaan, jika $x y$ adalah busur Graph $G$. jika semua simpul dalam Graph $G$ saling berpasangan satu sama lain, maka Graph $G$ disebut komplet (complete) dituliskan dengan $K^{n}$, dimana $n$ adalah jumlah dari simpul.

$k$-ketetanggaan terdekat $(k-N N)$ dari simpul $i$ bisa diperoleh dengan menarik sebuah lingkaran dengan berpusat pada simpul $i$ sampai diperoleh $k$ simpul lain yang berada dalam lingkaran. Gambar 2, 3-ketetanggaan terdekat dari simpul A adalah tiga simpul, yaitu simpul B, C, dan D. 7-ketetanggaan terdekat dari simpul A diperoleh dengan memperpanjang jari-jari lingkaran sampai diperoleh 7 simpul yang berada dalam lingkaran, yaitu simpul B, C, D, E, F, G, dan H. Dua simpul (I dan J) bukan anggota dari 7ketetanggaan terdekat dari simpul A, karena berada diluar lingkaran.

Graph terdiri dari berbagai jenis (Newman, 2003), yaitu Graph berarah, tak berarah, berbobot, dan tak berbobot. Graph tak berarah (undirected Graph) adalah pasangan busur $x y$ sama dengan pasangan busur $y x$. Busur tersebut dikatakan sebagai busur tak berarah. Simpul $x$ dan $y$ disebut sebagai titik akhir (endpoint). Sebuah Graph G disebut Graph tak berarah jika setiap busurnya terhubung tak berarah (Levitin, 2005).

Jika pasangan busur $x y$ tidak sama dengan busur $y x$, maka busur tersebut disebut sebagai busur berarah. Busur $x y$ meninggalkan $x$ menuju $y$ disebut juga $x$ sebagai ekor, dan $y$ sebagai kepala. Graph $G$ disebut sebagai Graph berarah jika semua busur terhubung secara berarah (Levitin, 2005). Gambar 3a adalah contoh penggambaran dari Graph tak berarah. Busur yang menghubungkan antar simpul tidak mempunyai tanda arah. Gambar $\mathbf{3 b}$ adalah contoh Graph berarah. Busur antar simpul pada Gambar 3b mempunyai simbol anak panah yang menunjukkan arah hubungan dari simpul ekor ke simpul kepala. Simpul $c$ dan $f$ mempunyai dua busur, yaitu $c f$ dan $f c$.

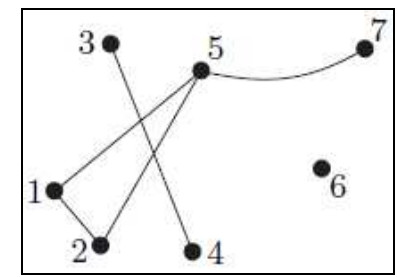

Gambar 1. Graph dengan tujuh simpul dan empat busur (Diestel, 2000).

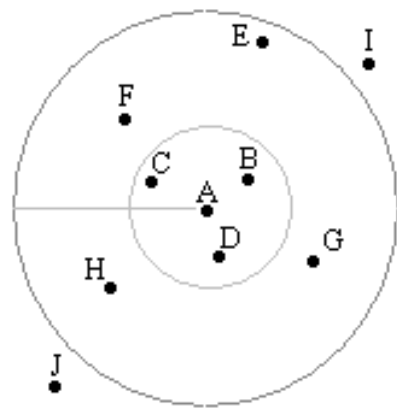

Gambar 2. Ilustrasi k-ketetanggaan terdekat

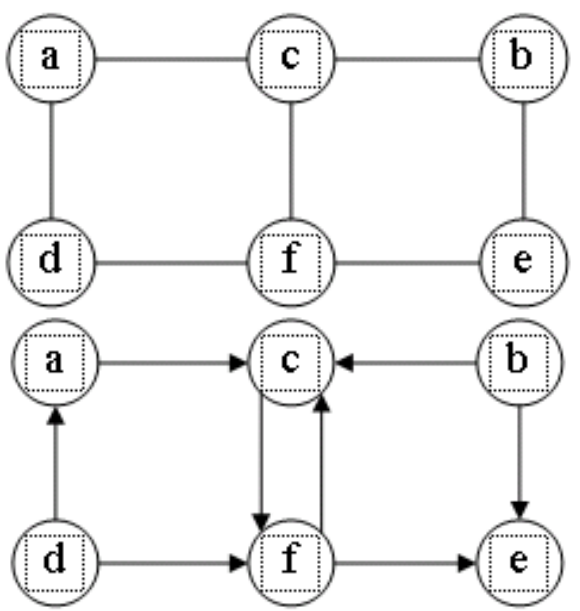

Gambar 3. Graph tidak berarah dan berarah.

(a) Graph tak berarah, (b) Graph berarah

(Levitin, 2005)

Untuk kepentingan suatu komputasi atau sebuah algoritma, secara umum Graph dapat digambarkan dengan bentuk matriks, disebut sebagai matriks adjacency. Matriks adjacency dari Graph dengan ukuran $n$ adalah matriks $n \times n$. Setiap elemen dari matriks mewakili satu busur dari Graph. Elemen baris ke $i$ dan kolom ke $j$ bernilai satu jika simpul ke $i$ terhubung dengan simpul ke $j$. Elemen baris ke $i$ dan kolom ke $j$ bernilai nol jika simpul ke $i$ tidak terhubung dengan simpul ke $j$ (Levitin, 2005). Gambar 4 
merupakan adjacency matriks dari Graph tak berarah pada Gambar 3a. Graph tak berarah mempunyai matriks adjacency yang simetris.

Graph berbobot (weigthed graph) merupakan Graph dengan suatu nilai pada simpul atau busur. Graph tak berbobot (unweigthed Graph) adalah Graph dengan simpul dan busurnya tidak mempunyai nilai. Nilai bisa hanya dimiliki oleh salah satu elemen dari Graph, simpul saja atau hanya busur. Tetapi yang sering, nilai dimiliki oleh busur. Nilai pada simpul digunakan untuk mewakili jumlah keanggotaan, luasan, atau besaran suatu simpul. Nilai pada busur digunakan untuk mewakili jumlah busur yang terhubung dengan sepasang simpul, jarak dua simpul, atau biaya yang dibutuhkan untuk melewati busur. Gambar 5 adalah contoh Graph berbobot dengan matriks adjacency.

\begin{tabular}{|c|c|c|c|c|c|c|}
\hline & $\mathrm{a}$ & \multicolumn{1}{c}{$\mathrm{b}$} & $\mathrm{c}$ & $\mathrm{D}$ & $\mathrm{e}$ & $\mathrm{f}$ \\
\hline $\mathrm{a}$ & 0 & 0 & 1 & 1 & 0 & 0 \\
\cline { 2 - 7 } $\mathrm{b}$ & 0 & 0 & 1 & 0 & 0 & 1 \\
\cline { 2 - 7 } $\mathrm{c}$ & 1 & 1 & 0 & 0 & 1 & 0 \\
\cline { 2 - 7 } $\mathrm{d}$ & 1 & 0 & 0 & 0 & 1 & 0 \\
\cline { 2 - 7 } $\mathrm{e}$ & 0 & 0 & 1 & 1 & 0 & 1 \\
\cline { 2 - 7 } $\mathrm{f}$ & 0 & 1 & 0 & 0 & 1 & 0 \\
\hline
\end{tabular}

Gambar 4. Graph dalam adjacency matriks (Levitin, 2005)

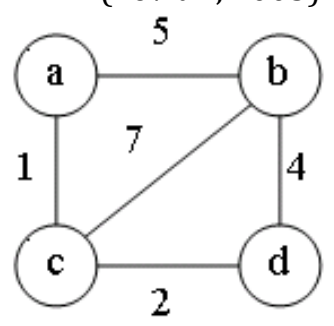

\begin{tabular}{|l|l|l|l|l|} 
& $a$ & $b$ & $c$ & $d$ \\
\hline$a$ & 0 & 5 & 1 & 0 \\
\hline$b$ & 5 & 0 & 7 & 4 \\
\hline$c$ & 1 & 7 & 0 & 2 \\
\hline$d$ & 0 & 4 & 2 & 0 \\
\hline
\end{tabular}

Gambar 5. (a) Graph berbobot, (b) matriks dari Graph berbobot.

Ditinjau dari jumlah penghubung dalam setiap simpul, terdapat pasangan simpul dengan busur jamak (multi edge) dan pasangan simpul dengan busur secara tunggal (single edge). Graph dengan busur jamak, simpul $x$ dan $y$ dihubungkan dengan lebih dari satu simpul. Gambar 3b merupakan Graph berbusur jamak. Peng-gambaran dalam matriks adjacency berupa matriks berbobot. Bobot dalam Graph busur jamak mewakili dari jumlah busur yang menghubungkan antara simpul $x$ dan simpul $y$.

\section{B. Random Graph}

Random Graph pertama kali dikenalkan oleh Erdős dan Rényi tahun 1959 (Diestel, 2000). Random Graph adalah Graph dengan simpul sejumlah $n$ dan setiap pasang simpulnya terhubung atau tidak terhubung dengan suatu probabilitas $p$ atau (1-p) (Newman, 2003). Random Graph di atas dinotasikan sebagai $G_{n, p}$. Secara teknis, Graph $G$ dengan $m$ adalah jumlah busur yang muncul, maka probabilitas kemunculan busur dinyatakan dalam persamaan 8.

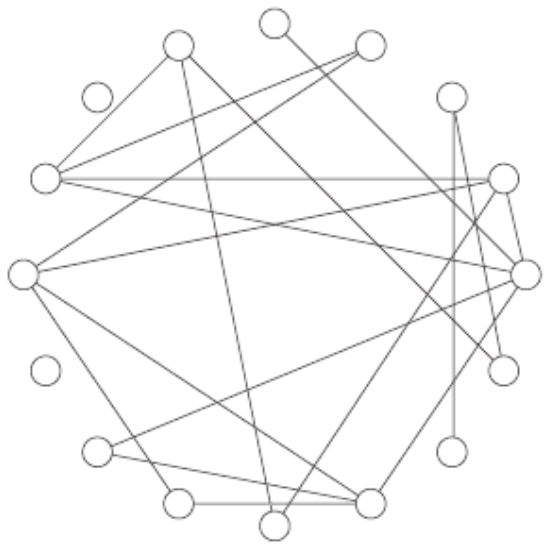

Gambar 6. Graph dibangun dengan model Erdos dan Renyi, $\mathrm{N}=16$ dan $p=1 / 7$ (Newman, 2001c)

$$
p^{m}(1-p)^{M-m}
$$

dimana

$$
M=1 / 2 n(n-1) .
$$

dengan $\mathrm{M}$ adalah maksimum jumlah busur yang mungkin terjadi, persamaan 9. Dari persamaan 8 dan 9 di atas, sering muncul random Graph yang dinotasikan dengan $G_{n, m}$. Gambar 6 merupakan contoh random Graph yang dibangun dengan model Erdos dan Renyi dengan probabilitas, $p=$ $1 / 7$.

\section{BAHAN DAN METODE}

\section{A. Bahan}

Bahan untuk uji coba pembatasan $k$ ketetanggaan simpul menggunakan citra tiruan berwarna hitam. Citra tiruan hitam penuh dikenakan pengotoran dengan derau putih. Ukuran citra tiruan untuk uji coba adalah 200x500 piksel. Pengotoran citra hitam penuh dengan derau menggunakan teknik pengkotoran salt and paper (Gonzales, 2002). Tingkat kepadatan derau pada citra tiruan mulai 0,003 dan 0,201. Citra tiruan yang dipakai untuk bahan uji coba sejumlah 100 buah.

Citra tiruan yang telah dikotori dengan derau putih digunakan sebagai bahan model dari 
Graph. Satu piksel putih pada citra tiruan dianggap sebagai sebuah simpul pada Graph. Model menghasilkan Graph dengan simpulsimpul yang tersebar secara acak. Graph yang dihasilkan berupa Graph dengan simpul-simpul yang tidak saling terhubung atau disebut sebagai Graph terisolasi. Simpul-simpul dalam Graph terisolasidigunakan sebagai bahan untuk membangkitkan busur-busur dengan metode erdos royi. Gambar 7 potongan dari citra dengan ukuran 20x50 piksel yang telah diperbesar 400\%.

Data jumlah simpul pada 100 citra tiruan hasil pengkotoran citra hitam penuh dengan menggunakan teknik pengkotoran salt and paper terdapat di dalam Tabel 1. Pada Tabel 1 tercantum jumlah simpul atau piksel putih dan tingkat kepadatan simpul dalam citra tiruan. Jumlah simpul terkecil 61 buah dan terbesar adalah 9951. Variasi jumlah simpul untuk mengetahui kelebihan dan kelemahan random Graph dengan metode erdos royi dengan $k$-NN.

\section{B. Metode}

Metode untuk menurunkan komputasi pembentukan Graph dengan metode random Graph erdos dan royi terdiri dari tiga tahapan. Tiga tahapan itu adalah : inisialisasi Graph, mencari $k$ ketetanggaan simpul, dan menghubungkan setiap simpul dengan $k$ tetangga dengan probabilitas $P$. Gambar 8 diagram alir metode random Graph erdos royi dengan $k$-NN.

1) Inisialisasi Graph

Pada tahapan inisialisasi Graph digunakan untuk menentukan nilai-nilai parameter awal yang dipakai untuk membangun random Graph metode erdos royi yang diintegrasikan dengan $k$-NN. Dua paramater awal adalah jumlah ketanggaan dari setiap simpul, $k$ dan jarak terjauh dari semua pasangan simpul, $L$.

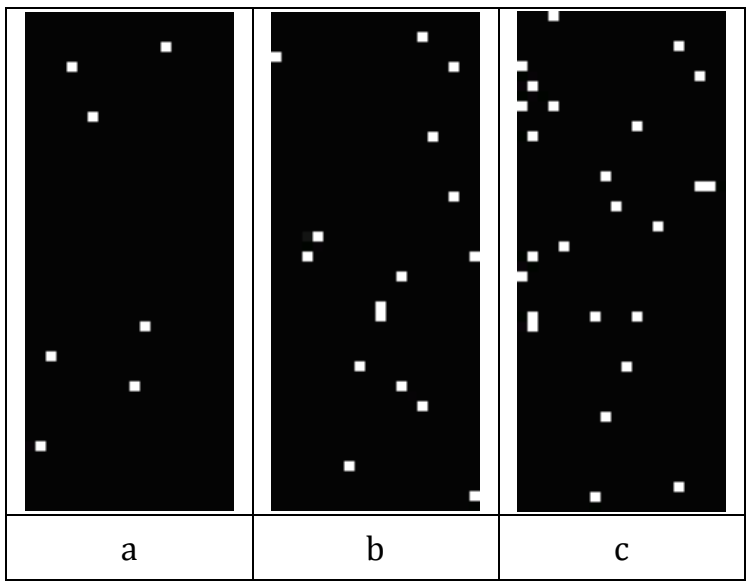

Gambar 7. Citra sampel yang telah dikotori dengan salt and paper. (a) potongan dari citra dengan jumlah simpul 937. (b) potongan dari citra yang telah terkotori dengan jumlah simpul
2041. (c) potongan dari citra yang telah terkotori dengan jumlah simpul 2933.

$$
P(v, u)=\alpha \cdot e^{-d(u, v) / \beta \cdot L} .
$$

Nilai $L$ digunakan untuk menentukan nilai probabilitas antar dua simpul , $P(u, v)$, dengan metode waxman (Gunduz, 2004), persamaan 2, dimana $\alpha$ dan $\beta$ adalah bilangan konstan dengan besar antara nol sampai dengan satu. $d(u, v)$ adalah jarak euclidean antara simpul $u$ dan $v$. Dalam Graph, $L$ bisa diperoleh dengan persamaan 3, dimana skala adalah lebar dimensi dari Graph. Dalam penelitian ini, Graph dibangun berdasarkan citra, maka $L$ diperoleh dari panjang diagonal citra, persamaan 4 , dimana $p$ dan $l$ merupakan panjang dan lebar citra sampel.

$$
\begin{aligned}
& L=\sqrt{2} \cdot \text { skala }, \\
& L=\sqrt{p^{2}+l^{2}},
\end{aligned}
$$

Random Graph metode erdos royi menghubungkan setiap simpul ( $n$ ) ke semua simpul lain (n-1). Keterhubungan pasangan simpul memperhatikan probabilitas waxman, seperti dalam persamaan 2. Dengan kata lain, random Graph metode erdos dan royi mencoba memeriksa keterhubungan semua kemungkinan pasangan simpul, $n(n-1)$.

Di sisi lain, jika Graph $G$ dengan setiap simpul dihubungkan dengan $k$ ketetanggaan dan $k$ jauh lebih besar dari $\ln (n)$, maka Graph $G$ dijamin menjadi Graph terhubung (Watts dan Strogatz, 1998, Distel, 2000), sesuai persamaan 5. Syarat agar random Graph menjadi terhubung, seperti pada persamaan 6 (Watts dan Strogatz, 1998, Distel,2000).

$$
\begin{aligned}
& k \gg \ln (n) . \\
& n \gg>>>\ln (n)>>1 .
\end{aligned}
$$

Dalam penelitian ini, untuk mendapatkan nilai $k$ jauh lebih besar dari $\ln (n), k$ diperoleh dengan dua pangkat pembulatan ke bawah $\ln (n)$, seperti persamaan 7 .

$$
k=2^{\lfloor\ln (n)\rfloor} .
$$

Random Graph metode erdos dan royi dengan $k$-NN menghubungkan setiap simpul $(n)$ dengan $k$ ketetanggaannya. Sehingga Graph dapat dihasilkan dengan random Graph metode erdos dan royi dengan $k$-NN. Komputasi dari random Graph metode erdos dan royi dengan $k$-NN adalah $n\left(k+k^{2}\right)$.

\section{2) Mencari k Ketetanggaan Simpul.}

Setelah diperoleh jumlah tetangga dari setiap simpul adalah $k$, tahapan selanjutnya 
adalah mencari simpul yang menjadi tetangga dari setiap simpul dengan jumlah $k$. $k$ tetangga terdekat dapat diperoleh dengam membuat jendela persegi panjang. Ukuran panjang sisi adalah pembulatan ke atas akar $k$, seperti persamaan 8.

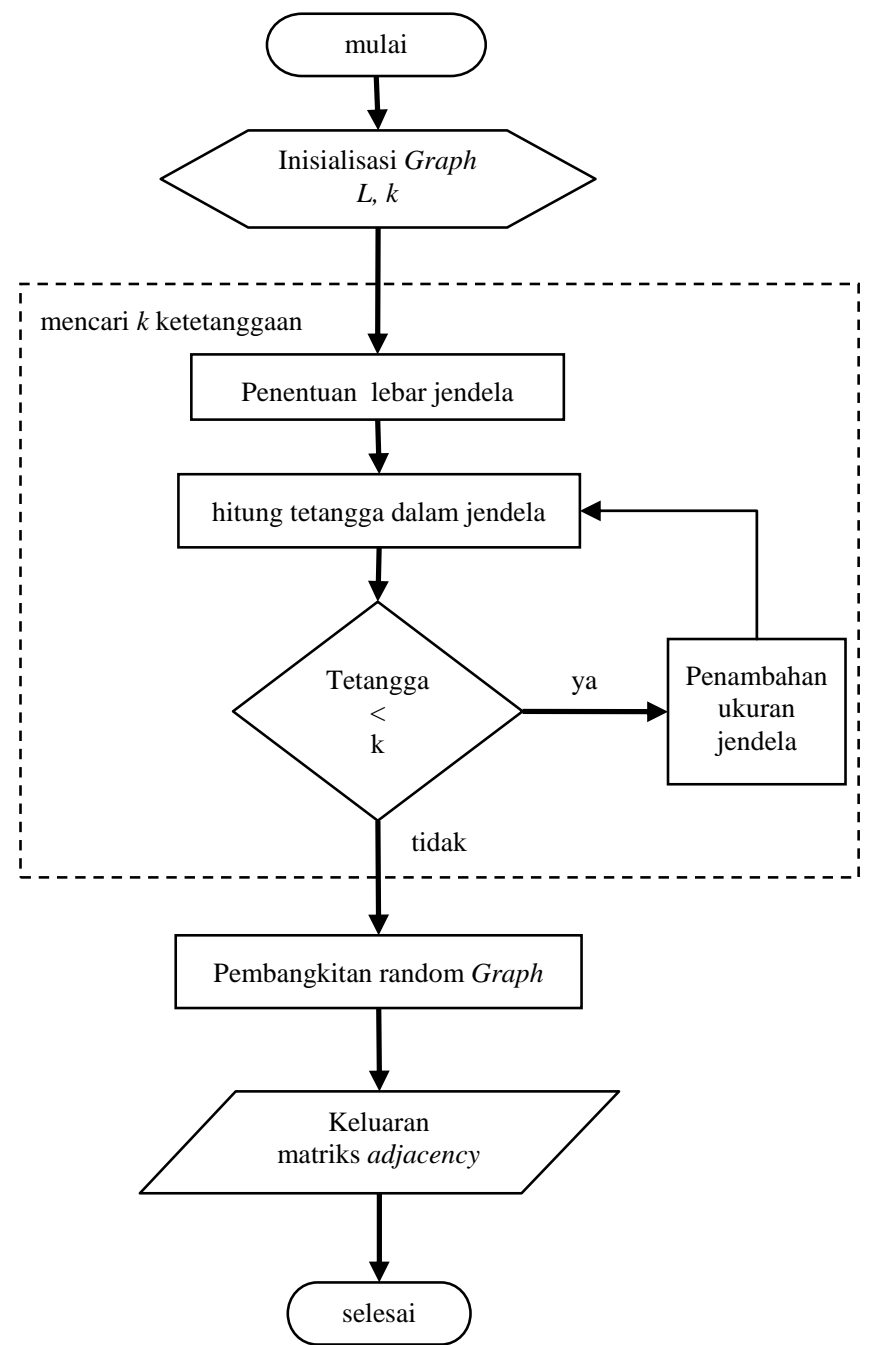

Gambar 8. Diagram alir metode random Graph erdos dan royi dengan $k$-NN

Tabel 1.Data jumlah simpul dalam citra tiruan untuk uji coba

\begin{tabular}{|l|l|l|}
\hline Nama File & Kerapatan & $\begin{array}{l}\text { Jumlah } \\
\text { simpul }\end{array}$ \\
\hline UG001.TIF & 0.003 & 61 \\
\hline UG002.TIF & 0.005 & 153 \\
\hline UG003.TIF & 0.007 & 257 \\
\hline UG004.TIF & 0.009 & 351 \\
\hline UG005.TIF & 0.011 & 459 \\
\hline UG006.TIF & 0.013 & 559 \\
\hline UG007.TIF & 0.015 & 610 \\
\hline UG008.TIF & 0.017 & 789 \\
\hline UG009.TIF & 0.019 & 919 \\
\hline UG010.TIF & 0.021 & 937 \\
\hline UG011.TIF & 0.023 & 1080 \\
\hline UG012.TIF & 0.025 & 1101 \\
\hline UG013.TIF & 0.027 & 1258 \\
\hline UG014.TIF & 0.029 & 1338 \\
\hline
\end{tabular}

\begin{tabular}{|c|c|c|}
\hline UG015.TIF & 0.031 & 1482 \\
\hline UG016.TIF & 0.033 & 1627 \\
\hline UG017.TIF & 0.035 & 1695 \\
\hline UG018.TIF & 0.037 & 1781 \\
\hline UG019.TIF & 0.039 & 1861 \\
\hline UG020.TIF & 0.041 & 2041 \\
\hline UG021.TIF & 0.043 & 2156 \\
\hline UG022.TIF & 0.045 & 2192 \\
\hline UG023.TIF & 0.047 & 2237 \\
\hline UG024.TIF & 0.049 & 2289 \\
\hline UG025.TIF & 0.051 & 2482 \\
\hline UG026.TIF & 0.053 & 2481 \\
\hline UG027.TIF & 0.055 & 2713 \\
\hline UG028.TIF & 0.057 & 2836 \\
\hline UG029.TIF & 0.059 & 2889 \\
\hline UG030.TIF & 0.061 & 2933 \\
\hline UG031.TIF & 0.063 & 3046 \\
\hline UG032.TIF & 0.065 & 3167 \\
\hline UG033.TIF & 0.067 & 3384 \\
\hline UG034.TIF & 0.069 & 3397 \\
\hline UG035.TIF & 0.071 & 3504 \\
\hline UG036.TIF & 0.073 & 3540 \\
\hline UG037.TIF & 0.075 & 3572 \\
\hline UG038.TIF & 0.077 & 3673 \\
\hline UG039.TIF & 0.079 & 3837 \\
\hline UG040.TIF & 0.081 & 4004 \\
\hline UG041.TIF & 0.083 & 3970 \\
\hline UG042.TIF & 0.085 & 4082 \\
\hline UG0 43.TIF & 0.087 & 4221 \\
\hline UG0 44 . TIF & 0.089 & 4424 \\
\hline UG045.TIF & 0.091 & 4417 \\
\hline UG046.TIF & 0.093 & 4491 \\
\hline UG047.TIF & 0.095 & 4631 \\
\hline UG048.TIF & 0.097 & 4778 \\
\hline UG049.TIF & 0.099 & 4696 \\
\hline UG050.TIF & 0.101 & 4897 \\
\hline UG051.TIF & 0.103 & 5036 \\
\hline UG052.TIF & 0.105 & 5150 \\
\hline UG053.TIF & 0.107 & 5249 \\
\hline UG054.TIF & 0.109 & 5336 \\
\hline UG055.TIF & 0.111 & 5428 \\
\hline UG056.TIF & 0.113 & 5546 \\
\hline UG057.TIF & 0.115 & 5685 \\
\hline UG058.TIF & 0.117 & 5773 \\
\hline UG059.TIF & 0.119 & 5925 \\
\hline UG060.TIF & 0.121 & 5952 \\
\hline UG061.TIF & 0.123 & 6041 \\
\hline UG062.TIF & 0.125 & 6088 \\
\hline UG063.TIF & 0.127 & 6072 \\
\hline UG064.TIF & 0.129 & 6255 \\
\hline UG065.TIF & 0.131 & 6515 \\
\hline UG066.TIF & 0.133 & 6409 \\
\hline UG067.TIF & 0.135 & 6542 \\
\hline UG068.TIF & 0.137 & 6736 \\
\hline UG069.TIF & 0.139 & 6794 \\
\hline UG070.TIF & 0.141 & 6991 \\
\hline UG071.TIF & 0.143 & 7017 \\
\hline UG072.TIF & 0.145 & 7217 \\
\hline UG073.TIF & 0.147 & 7297 \\
\hline UG074.TIF & 0.149 & 7281 \\
\hline UG075.TIF & 0.151 & 7502 \\
\hline UG076.TIF & 0.153 & 7543 \\
\hline UG077.TIF & 0.155 & 7611 \\
\hline UG078.TIF & 0.157 & 7843 \\
\hline UG079.TIF & 0.159 & 7906 \\
\hline
\end{tabular}




\begin{tabular}{|l|l|l|} 
UG080.TIF & 0.161 & 7995 \\
\hline UG081.TIF & 0.163 & 7986 \\
\hline UG082.TIF & 0.165 & 8135 \\
\hline UG083.TIF & 0.167 & 8362 \\
\hline UG084.TIF & 0.169 & 8276 \\
\hline UG085.TIF & 0.171 & 8564 \\
\hline UG086.TIF & 0.173 & 8592 \\
\hline UG087.TIF & 0.175 & 8787 \\
\hline UG088.TIF & 0.177 & 8709 \\
\hline UG089.TIF & 0.179 & 8724 \\
\hline UG090.TIF & 0.181 & 9087 \\
\hline UG091.TIF & 0.183 & 9044 \\
\hline UG092.TIF & 0.185 & 9092 \\
\hline UG093.TIF & 0.187 & 9170 \\
\hline UG094.TIF & 0.189 & 9537 \\
\hline UG095.TIF & 0.191 & 9380 \\
\hline UG096.TIF & 0.193 & 9504 \\
\hline UG097.TIF & 0.195 & 9693 \\
\hline UG098.TIF & 0.197 & 9667 \\
\hline UG099.TIF & 0.199 & 9886 \\
\hline UG100.TIF & 0.201 & 9951 \\
\hline
\end{tabular}

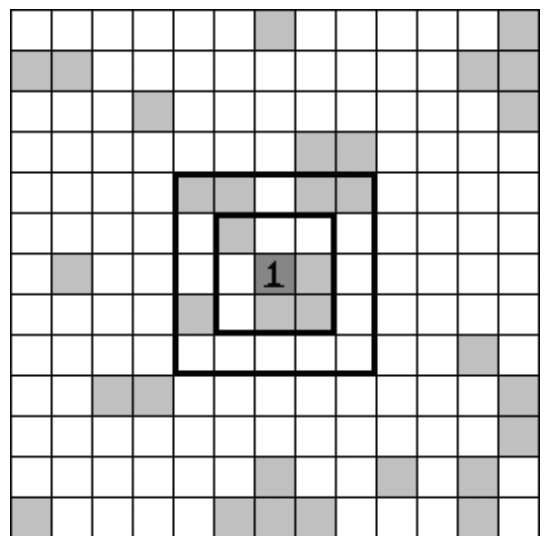

Gambar 9 : Ilustrasi pembuatan jendela $k$-NN dengan $n=34$ dan $k=8$,

$$
|\sqrt{k}| \text {. }
$$

Diasumsikan bahwa semua bagian dalam jendela terisi dengan simpul secara penuh. Jika semua bagian jendela terisi penuh, maka terdapat jumlah tetangga $>=\mathrm{k}$. Jika dalam jendela terdapat tetangga terdekat kurang dari $k$, maka lebar sisi jendela ditambah sebesar $k / 2$. Gambar 9 merupakan ilustrasi pembuatan jendela $k$-NN. Ukuran Graph 34, diperoleh $\ln (n)=3,5$ sehingga $k$ $=8$.

Pada ilustrasi dicari 8-ketetanggaan dari titik berlabel angka satu. Proses inisialisasi diperoleh lebar jendela tiga dan titik yang menjadi tetangganya delapan. Pada jendela ukuran 3x3 hanya terdapat empat simpul tetangga, jumlah simpul masih kurang dari $k$. Lebar jendela ditambah untuk mendapatkan jumlah tetangga lebih besar atau sama dengan $k$. Hasil dari penambahan lebar jendela diperoleh simpul tetangga sejumlah sembilan.

3) Pembangkitan Random Graph
Setiap memperoleh $k$ tetangga terdekat, suatu simpul dibuat busur yang menghubungkan simpul dengan semua $k$ tetangganya. Dalam pembentukan Graph ditetapkan suatu nilai probabilitas setiap pasang simpul, $P$, dengan persamaan 2 Dengan kondisi di atas bisa di hasilkan random Graph $\mathrm{G}_{n, p}$.

Tabel 2. Simulasi perhitungan probalitas

\begin{tabular}{|c|c|}
\hline$D$ & waxman \\
\hline 1 & 0.2309609 \\
\hline 2 & 0.0561505 \\
\hline 3 & 0.0136511 \\
\hline 4 & 0.0033188 \\
\hline 5 & 0.0008069 \\
\hline 6 & 0.0001962 \\
\hline 7 & 0.0000477 \\
\hline 8 & 0.0000116 \\
\hline 9 & 0.0000028 \\
\hline 10 & 0.0000007 \\
\hline
\end{tabular}

Persamaan 2 menghasilkan probabilitas yang mendekati satu sampai mendekati nol. Jika jarak euclidean antara dua buah titik semakin dekat maka probabilitasnya semakin besar. Demikian pula sebaliknya, jika jaraknya jauh maka probabilitasnya semakin kecil, cenderung nol. Tabel 2 uji coba rumus 21 dalam simulasi sepuluh angka dengan lebar skala 10x10.

\section{4) Pembangunan Graph}

Hasil dari proses penentuan obyek berupa citra biner, nilai nol dan satu di citra biner dijadikan acuan pembentukan Graph. Piksel bernilai satu dianggap sebagai sebuah simpul. Asumsi bahwa simpul-simpul dalam sampel sebagai simpul terasing yang tidak terhubung dengan busur. Gambar $\mathbf{1 0}$ merupakan citra tiruan simpul-simpul yang tersimpan dalam citra biner. Dalam citra tiruan terdapat 144 piksel putih yang berarti terdapat 144 simpul terasing. Satu kotak kecil berisikan 9 piksel putih.

Pembentukan Graph diawali dengan penghubungan setiap simpul dari citra sampel dengan busur. Pembangkitan busur-busur dalam pembentukan graph menggunakan random graph metode erdos dan royi dengan $k$-NN. Simpul yang saling terhubung dihitung probabilitasnya menggunakan metode waxman, persamaan 2 . Nilai probabilitas rendah menunjukan bahwa dua simpul mempunyai jarak yang jauh (panjang). Sebaliknya probabilitas tinggi menunjukkan bahwa dua simpul mempunyai jarak yang dekat (pendek), lihat Tabel 2. 
Keterhubungan antar dua simpul dibatasi dengan nilai ambang. Jika nilai probabilitas dua simpul lebih kecil dari nilai ambang, maka busur yang menghubungkan dua simpul tersebut dihapus. Tujuan dari pemotongan garis penghubung yang mempunyai probabilitas rendah adalah untuk menghapus hubungan dua simpul yang jauh. Manfaatnya, simpul hanya terhubung dengan simpul-simpul yang dekat, sehingga dapat diketahui nilai-nilai karakter dari setiap simpul terhadap simpul tetangga terdekatnya.

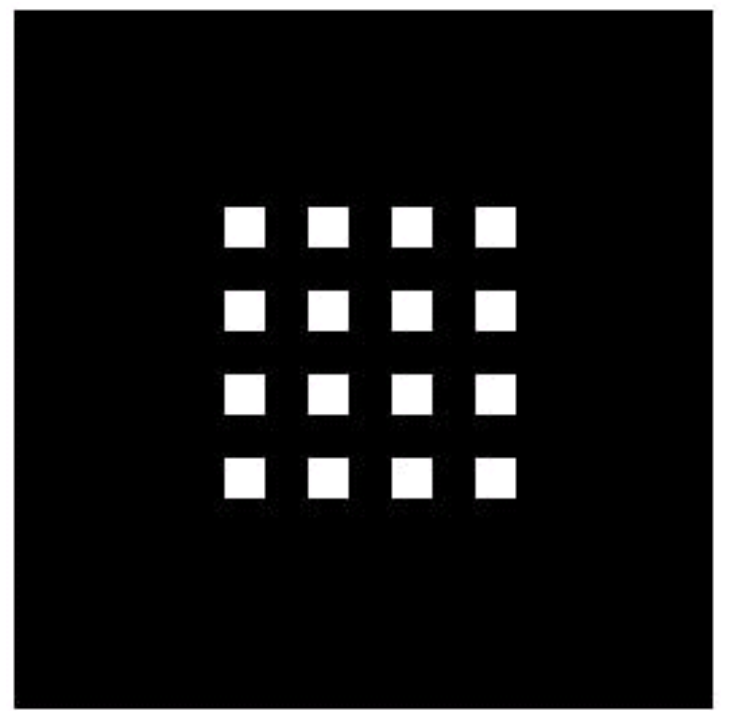

Gambar 10. Citra tiruan simpul

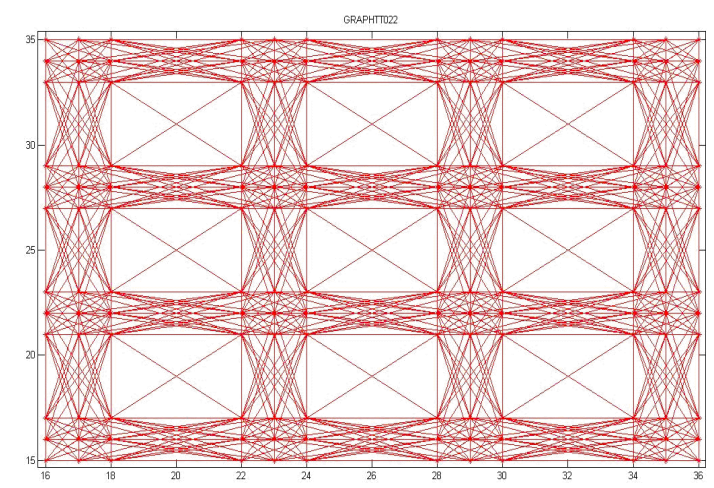

Gambar 11. Graph dari citra tiruan.

Gambar 10 merupakan Graph hasil dari citra tiruan. Setiap simpul pada citra tiruan dihubungkan dengan nilai ambang probabilitas 0.2 dari citra berukuran 50x50. Tampak graph dengan simpul-simpul yan saling berdekatan mempunyai busur lebih banyak dibandingkan dengan yang letaknya berjauhan. Jumlah busur dari sebuah simpul dipengaruhi jumlah simpul tetangga yang dekat dan jarak antar simpul tetangga.

Tampak pada gambar 11, simpul-simpul yang mempunyai jarak dekat dengan tetangganya mempunyai jumlah busur lebih banyak dibandingkan dengan simpul yang jarak antar tetangganya jauh. Jumlah busur pada setiap simpul merupakan degree dari simpul tersebut. Simpul yang mempunyai degree tinggi adalah simpul yang dikelilingi oleh simpul lain dengan jarak yang dekat. Sebaliknya simpul dengan degree rendah adalah simpul yang di sekitarnya terdapat simpul-simpul dengan jarak yang cenderung jauh. Simpul dengan jumlah tetangga sedikit cenderung mempunyai degree rendah. Simpul dengan tetangga sedikit biasanya berada dipinggir suatu area.

\section{APLIKASI DAN PEMBAHASAN}

\section{1) Lingkungan Uji Coba}

Uji coba lakukan di komputer Acer Aspire 3610. Perangkat keras pendukungnya adalah prosesor $1.8 \mathrm{GHz}$, Kapasitas memori 2 Gbyte, Kapasitas Harddisk 40 Gbyte. Perangkat lunak pendukung adalah i windows xp service pack 1, Bahasa pemrograman menggunakan matlab versi 7.1

\section{2) Skenario Uji Coba}

Uji coba random Graph metode erdos royi dengan $k$-NN. Uji Coba akan membandingkan random Graph metode erdos royi murni dengan random Graph metode erdos royi dengan $k$-NN. Uji Coba ini untuk melihat kebutuhan waktu komputasi dari masing-masing metode.

Uji coba dilaksanakan guna mengetahui keberhasilan random Graph metode erdos dan royi dengan $k$-NN dalam menurunkan waktu komputasi pada saat membangkitkan suatu graph. Metode diujicobakan dengan 100 data (tabel 4.1). Data berupa citra yang dikotori dengan derau menggunakan teknik pengkotoran salt and paper (Gonzalez, 2002). Semua piksel putih dalam citra dianggap sebagai simpulsimpul terasing pada Graph. Semua data digunakan untuk masukan dalam pembangkitan random Graph menggunakan metode erdos dan royi. Kemudian hasil coba pertama dibandingkan dengan hasil uji coba pembangkitan random Graph yang dilaksanakan dengan metode erdos dan royi dengan $k$-NN.

\section{3) Pelaksanaan dan Evaluasi Uji Coba}

Uji coba dilaksanakan sesuai dengan skenario yang telah dibahas pada subbab Skenario Uji Coba. Uji coba dilaksanakan untuk mengevaluasi hasil-hasil uji coba.Hasil metode erdos royi murni dibandingkan dengan erdos royi dengan $k$-NN. Kedua metode diujicobakan pada citra tiruan diperoleh dari citra hitam penuh yang dikotori dengan derau. Pengkotoran menggunakan metode pengkotoran salt and 
paper (Gonzalez, 2002). Jumlah citra 100 dengan kerapatan mulai 0.002 sampai dengan 0.2. Jumlah piksel putih lebih lengkap dapat dilihat pada Tabel 1. Perlakuan uji coba kedua metode dikenakan pada lingkungan uji coba tertera pada Tabel 3.

Gambar 12 perbandingan waktu komputasi dari dua metode. Pada Gambar 12 waktu komputasi erdos royi lebih besar jika banding dengan erdos royi dengan $k$-NN. Data lebih lengkap tercantum dalam Tabel 4. Pada jumlah simpul kecil di bawah 1258, waktu komputasi random Graph metode erdos dan royi lebih cepat. Tetapi waktu komputasi random Graph metode erdos dan royi dengan $k$-NN tidak terlalu lambat dibanding dengan komputasi random Graph metode erdos dan royi murni.

Tabel 3 : Parameter uji coba random Graph.

\begin{tabular}{|l|l|}
\hline Parameter & \multicolumn{1}{|c|}{ Nilai } \\
\hline Probabilitas & 0,5 \\
\hline L & 538,516 \\
\hline Alfa & 0,95 \\
\hline Beta & 0,05 \\
\hline
\end{tabular}

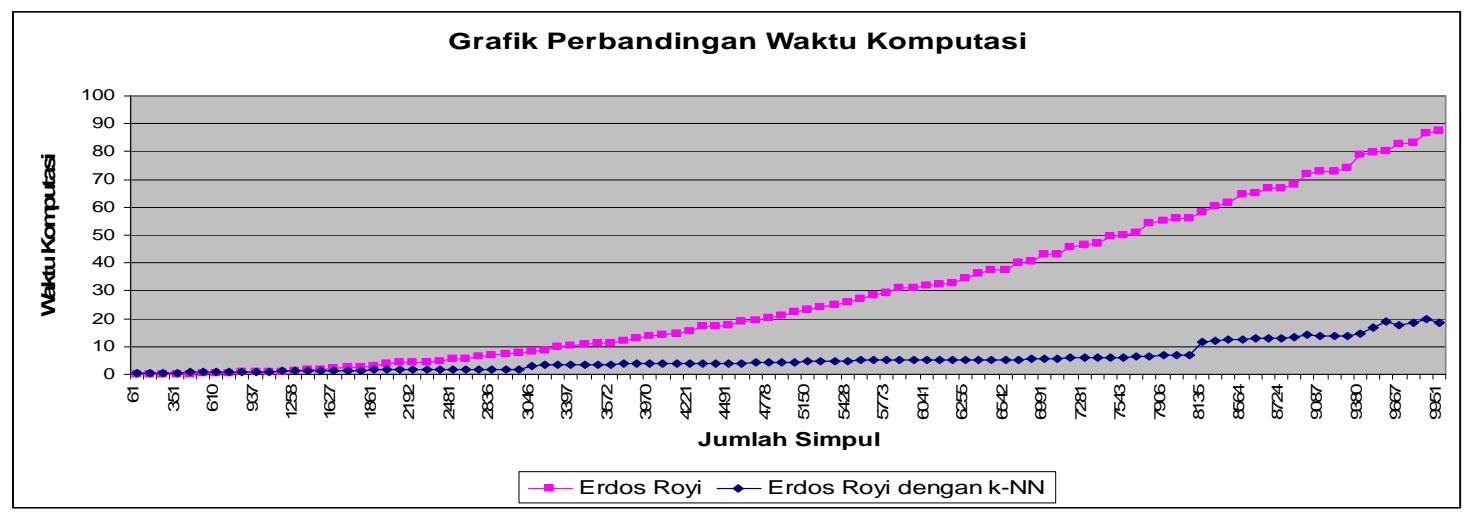

Gambar 12 : Grafik komputasi random Graph Erdos Royi dan Erdos Royi dengan $k$-NN.

Tabel 4 : Perbandingan waktu komputasi random Graph erdos dan royi dengan random Graph erdos royi $k$-NN.

\begin{tabular}{|r|c|c|c|}
\hline \multirow{2}{*}{$\begin{array}{l}\text { Jumlah } \\
\text { simpul }\end{array}$} & \multirow{2}{*}{ Kerapatan } & \multicolumn{2}{|c|}{ Waktu Komputasi } \\
\cline { 3 - 4 } & & ER k-NN & ER \\
\hline 61 & 0.003 & 0.57294 & 0.00697 \\
\hline 153 & 0.005 & 0.62569 & 0.02100 \\
\hline 257 & 0.007 & 0.54349 & 0.05890 \\
\hline 351 & 0.009 & 0.47827 & 0.10926 \\
\hline 459 & 0.011 & 0.88367 & 0.18505 \\
\hline 559 & 0.013 & 0.86169 & 0.27676 \\
\hline 610 & 0.015 & 0.86304 & 0.32878 \\
\hline 789 & 0.017 & 0.82398 & 0.55010 \\
\hline 919 & 0.019 & 0.83146 & 0.74452 \\
\hline 937 & 0.021 & 0.80041 & 0.77365 \\
\hline 1080 & 0.023 & 0.82323 & 1.02799 \\
\hline 1101 & 0.025 & 1.45573 & 1.06906 \\
\hline 1258 & 0.027 & 1.46713 & 1.39193 \\
\hline 1338 & 0.029 & 1.44778 & 1.57528 \\
\hline 1482 & 0.031 & 1.44725 & 1.93332 \\
\hline 1627 & 0.033 & 1.49927 & 2.32916 \\
\hline 1695 & 0.035 & 1.49051 & 2.52808 \\
\hline 1781 & 0.037 & 1.50575 & 2.79336 \\
\hline 1861 & 0.039 & 1.53051 & 3.04980 \\
\hline 2041 & 0.041 & 1.54944 & 3.66728 \\
\hline 2156 & 0.043 & 1.60874 & 4.09628 \\
\hline 2192 & 0.045 & 1.62677 & 4.23201 \\
\hline 2237 & 0.047 & 1.64248 & 4.40775 \\
\hline & & & \\
\hline
\end{tabular}

\begin{tabular}{|c|c|c|c|}
\hline 2289 & 0.049 & 1.63693 & 4.61314 \\
\hline 2481 & 0.051 & 1.67972 & 5.42537 \\
\hline 2482 & 0.053 & 1.67597 & 5.42627 \\
\hline 2713 & 0.055 & 1.74183 & 6.47728 \\
\hline 2836 & 0.057 & 1.81065 & 7.08220 \\
\hline 2889 & 0.059 & 1.83860 & 7.34796 \\
\hline 2933 & 0.061 & 1.84444 & 7.57942 \\
\hline 3046 & 0.063 & 3.15187 & 8.16770 \\
\hline 3167 & 0.065 & 3.23873 & 8.83156 \\
\hline 3384 & 0.067 & 3.54660 & 10.08787 \\
\hline 3397 & 0.069 & 3.46173 & 10.20142 \\
\hline 3504 & 0.071 & 3.50742 & 10.81216 \\
\hline 3540 & 0.073 & 3.65244 & 11.03016 \\
\hline 3572 & 0.075 & 3.64004 & 11.22606 \\
\hline 3673 & 0.077 & 3.67181 & 11.87704 \\
\hline 3837 & 0.079 & 3.76098 & 12.96722 \\
\hline 3970 & 0.081 & 3.73449 & 13.87264 \\
\hline 4004 & 0.083 & 3.73913 & 14.11632 \\
\hline 4082 & 0.085 & 3.75886 & 14.67194 \\
\hline 4221 & 0.087 & 3.70121 & 15.68447 \\
\hline 4417 & 0.089 & 3.80541 & 17.17473 \\
\hline 4424 & 0.091 & 3.83085 & 17.21913 \\
\hline 4491 & 0.093 & 3.91290 & 17.75805 \\
\hline 4631 & 0.095 & 4.01942 & 18.87249 \\
\hline 4696 & 0.097 & 4.10087 & 19.40843 \\
\hline 4778 & 0.099 & 4.19061 & 20.10800 \\
\hline 4897 & 0.101 & 4.29645 & 21.10801 \\
\hline 5036 & 0.103 & 4.47701 & 22.30385 \\
\hline 5150 & 0.105 & 4.63355 & 23.35821 \\
\hline
\end{tabular}




\begin{tabular}{|l|l|l|l|}
5249 & 0.107 & 4.73978 & 24.23739 \\
\hline 5336 & 0.109 & 4.80595 & 25.05935 \\
\hline 5428 & 0.111 & 4.92789 & 25.94123 \\
\hline 5546 & 0.113 & 5.00948 & 27.06993 \\
\hline 5685 & 0.115 & 5.16376 & 28.43455 \\
\hline 5773 & 0.117 & 5.19992 & 29.34578 \\
\hline 5925 & 0.119 & 5.17961 & 30.91552 \\
\hline 5952 & 0.121 & 5.20977 & 31.16242 \\
\hline 6041 & 0.123 & 5.20647 & 32.10460 \\
\hline 6072 & 0.125 & 5.29950 & 32.45810 \\
\hline 6088 & 0.127 & 5.24221 & 32.61672 \\
\hline 6255 & 0.129 & 5.20859 & 34.42880 \\
\hline 6409 & 0.131 & 5.20513 & 36.13983 \\
\hline 6515 & 0.133 & 5.22762 & 37.36209 \\
\hline 6542 & 0.135 & 5.26608 & 37.65784 \\
\hline 6736 & 0.137 & 5.32041 & 39.93466 \\
\hline 6794 & 0.139 & 5.40414 & 40.61880 \\
\hline 6991 & 0.141 & 5.62366 & 43.02693 \\
\hline 7017 & 0.143 & 5.63420 & 43.31324 \\
\hline 7217 & 0.145 & 5.84581 & 45.84301 \\
\hline 7281 & 0.147 & 5.90240 & 46.63678 \\
\hline 7297 & 0.149 & 5.93010 & 46.84052 \\
\hline 7502 & 0.151 & 6.24529 & 49.53723 \\
\hline 7543 & 0.153 & 6.22858 & 50.08511 \\
\hline 7611 & 0.155 & 6.30604 & 50.96423 \\
\hline 7843 & 0.157 & 6.65871 & 54.11894 \\
\hline 7906 & 0.159 & 6.72723 & 54.98794 \\
\hline 7986 & 0.161 & 6.76583 & 56.11708 \\
\hline 7995 & 0.163 & 6.84309 & 56.23221 \\
\hline 8135 & 0.165 & 11.69431 & 58.21586 \\
\hline 8276 & 0.167 & 12.07412 & 60.26962 \\
\hline 8362 & 0.169 & 12.30286 & 61.56285 \\
\hline 8564 & 0.171 & 12.70018 & 64.59212 \\
\hline 8592 & 0.173 & 12.79342 & 64.96993 \\
\hline 8709 & 0.175 & 13.00610 & 66.77934 \\
\hline 8724 & 0.177 & 13.08824 & 66.93141 \\
\hline 8787 & 0.179 & 13.16771 & 67.93681 \\
\hline 9044 & 0.181 & 14.28052 & 71.92699 \\
\hline 9087 & 0.183 & 13.72087 & 72.75217 \\
\hline 9092 & 0.185 & 13.75461 & 72.71987 \\
\hline 9170 & 0.187 & 13.69513 & 74.00391 \\
\hline 9380 & 0.189 & 14.59682 & 79.08805 \\
\hline 9504 & 0.191 & 16.60406 & 79.52803 \\
\hline 9537 & 0.193 & 18.77744 & 80.03217 \\
\hline 9667 & 0.195 & 17.57210 & 82.66109 \\
\hline 9693 & 0.197 & 18.70974 & 83.11653 \\
\hline 9886 & 0.199 & 19.80950 & 86.60223 \\
\hline 9951 & 0.201 & 18.38680 & 87.59296 \\
\hline & & & \\
\hline
\end{tabular}

Terlihat pada Tabel 4 bahwa random Graph metode erdos royi dengan $k$-NN lebih unggul pada posisi jumlah simpul lebih dari 1258. Penambahan jumlah simpul tidak menambah waktu komputasi secara signifikan. Penambahan waktu komputasi pada random Graph metode erdos dan royi dengan $k$-NN bertambah secara linier terhadap jumlah simpul. Waktu komputasi random Graph metode erdos dan royi bertambah secara eksponensial terhadap jumlah simpul.

Kelemahan erdos royi dengan $k$-NN adalah pada waktu komputasi untuk mencari $k$ ketetanggaan. Pada data dengan tingkat kepadatan simpul rendah, jarak antar simpul relatif berjauhan, sehingga pencarian simpul tetangga memerlukan waktu relatih lama. Data dengan tingkatan kepadatan simpul tinggi, waktu untuk pencarian simpul tetangga relatif cepat, karena dengan ukuran jendela yang tidak lebar tetangga simpul sejumlah $k$ dapat ditemukan. Pencarian ketetanggan pada area dengan kerapatan tinggi hanya memerlukan proses memperlebar jendela dengan waktu yang pendek. Pada area dengan jumlah simpul 1338 waktu komputasi dari random Graph metode erdos dan royi dengan $k$ NN.

Gambar 13b Graph hasil random Graph dari erdos royi. Gambar 13c Graph hasil random Graph dengan metode erdos royi dengan $k$-NN. Kedua Graph dibangkitkan dari citra biner (Gambar 13a) yang berisi 257 piksel putih dengan tingkat kepadatan 0.007. Graph pada Gambar 13 dibangkitkan dengan probabilitas 0,4 . Tampak dalam gambar bahwa dua graph yang dihasilkan tidak memiliki perbedaan, jumlah simpul yang terhubung oleh busur adalah sama, yaitu 252.

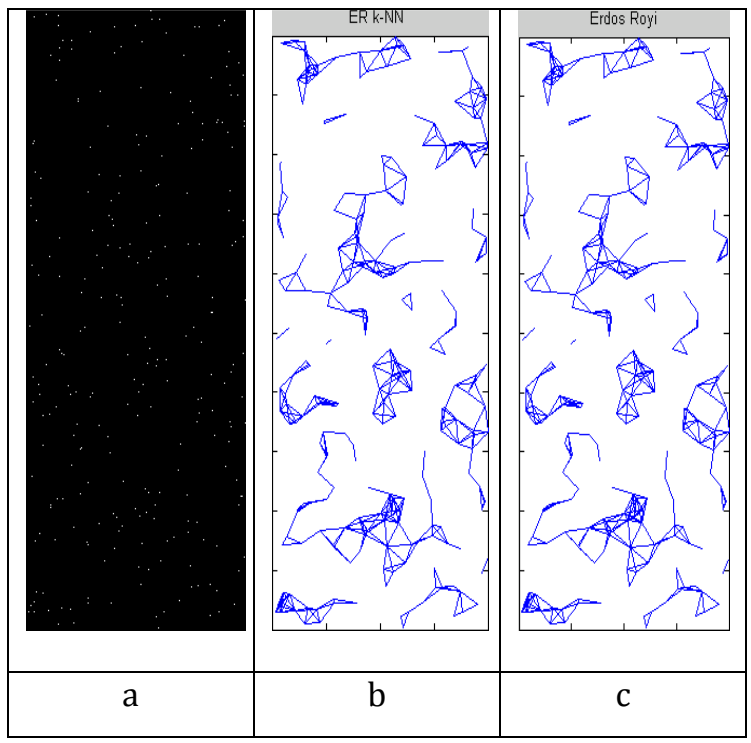

Gambar 13 : Contoh dari hasil uji coba random Graph, (a) Citra biner, (b) Erdos Royi, (c) Erdos Royi dengan $k$-NN.

Simpul-simpul pada Gambar 13a yang tidak terhubung oleh busur merupakan simpul yang mempunyai tetangga sangat jauh, atau probabilitasnya lebih kecil dari 0,5. Pasangan simpul yang probabilitasnya lebih kecil dari nilai ambang, maka busurnya tidak dihubungkan. Simpul-simpul dengan jarak yang saling berdekatan mempunyai busur yang banyak. Sim- 
pul-simpul dengan jarak yang saling berjauhan mempunyai busur yang sedikit.

Dari graph dapat diketahui jumlah simpul yang saling berdekatan dengan melihat jumlah busur yang terhubung dengan simpul. Simpul dengan jumlah busur (degree) besar berarti simpul mempunyai tetangga yang banyak. Dengan kata lain, simpul berada di area yang rapat.

\section{PENUTUP}

\section{A. Simpulan}

Waktu komputasi pada random Graph metode erdos dan royi dapat dikurangi dengan mengintegrasikan metode $k$-NN. $k$-NN digunakan untuk menghubungkan busur dari setiap simpul dengan $k$ tetangga terdekat. Random Graph metode erdos dan royi yang semula menghubungkan $n(n-1)$ simpul, setelah diintegrasikan dengan $k$ NN menjadi hanya menghubungkan $n(k)$ simpul. Waktu komputasi random Graph metode erdos dan royi $n(n-1)$, sedangkan Random Graph metode erdos dan royi dengan $k$-NN menjadi $\mathrm{n}\left(k+k^{2}\right)$, dimana $k$ adalah waktu untuk menghubungkan busur dari simpul ke $k$ jumlah tetangga, dan $k^{2}$ adalah waktu untuk mencari tetangga dalam jendela.

\section{B. Saran}

Pengurangan waktu komputasi pada random Graph erdos royi dengan $k$-NN masih terdapat waktu komputasi untuk mencari $\mathrm{k}$ ketetanggaan yang relatif besar. Waktu komputasi mencari $k$ ketetanggaan masih perlu dikurangi. Metode pembuatan jendela bisa ditingkatkan ketepatannya agar diperoleh $k$ ketetanggaan lebih tepat dan waktu pencarian $\mathrm{k}$ ketetanggaan lebih cepat.

\section{DAFTAR PUSTAKA}

[1] Abidin, Zainal dan Arifin Agus Z. 2008. Generation Graph with random Graph erdos royi method by medical image to help diagnoses of osteoporosis. International Conference Bio Medical Engenering 2008 di ITS Surabaya

[2] Abidin, Zainal dan Arifin Agus Z. 2009. Analisa Kerapatan Trabecular Bone Berbasis Graph Berbobot pada Citra Panorama Gigi untuk Identifikasi Osteoporosis. Jurnal Teknik Informatika Volume 7 Nomor 3 Januari 2009
[3] Albert, R., Barabasi, A. -L..(2002). "Statistical Mechanics of Complex Networks" Review of Modern Physics volume 75 halaman 47 - 98.

[4] Andre, M., Ijaz, K., Tillinghast, J. D., Krebs, V. E., Diem, L. A., Metchock, B., Crisp, T., McElroy, P. D.(2006) "Transmission Network Analysis to Complement Routine Tuberculosis Contact Investigations" American Journal of Public Healt. volume 96 nomor 11.

[5] Diestel, Reinhard (2000). Graph Theory Electronic Edition. Springer-Verlag: New York.

[6] Demir, C., Yener, B., dan Gultekin, S. H. (2005). "Augmented Cell-Graph for Automated Cancer Diagnosis". Bioinformatic Vol 21 suplemen 2. ii7-ii12

[7] Gonzalez, R. C., Woods, R. E., Eddins, S. L.. (2002). Digital Image Processing. Prentice Hall. New Jersey.

[8] Guesebroek, Jan-Mark., Smeulders, A.W .M., dan Cornellisen F (1999). "Segmentation of Tissue by Distance Graph Matching". Cytometry 35:11-22

[9] Gunduz, C., Yener, B., dan Gultekin, S. H. (2004). "The Cell Graphs of Cancer". Bioinformatic Vol. 20 suplemen 1.i145-i151.

[10] Levitin, Anany. (2007). Intoduction to The Design and Analysis of Algoritms second edition. Pearson Education, Inc.

[11] Newman, M. E. J.. (2001a). "Scientific Collaboration Network. II. Shostest Paths, Weighted Network, and Centrality". Physical review Vol. E64 016132

[12] Newman, M. E. J.. (2001b), "Who is the Best Connected Scientist ? A Study of Scientific Coauthorship Network". Physical review Vol. E64 0011144.

[13] Newman, M. E. J., (2001c), "Random Graph models of Sosial Network". Proc. Natl. Acad. Sci. USA 99. 2566-2572.

[14] Newman, M. E. J., 2003, "The Structure and Function of Complex Networks". SIAM review Vol. 45 Number 2 : 167-256

[15] Watts, D. J., Strogatz, S. H.. (1998). "Collective dynamics of 'small-word' models" Nature. Volume 393 halaman 440442. 